\title{
The role of the JAK2-STAT3 pathway in pro-inflammatory responses of EMF-stimulated N9 microglial cells
}

Xuesen Yang ${ }^{1,2+}$, Genlin $\mathrm{He}^{1,2+}$, Yutong Hao ${ }^{3}$, Chunhai Chen ${ }^{1}$, Maoquan $\mathrm{Li}^{1}$, Yuan Wang ${ }^{1}$, Guangbin Zhang ${ }^{1}$, Zhengping $\mathrm{Yu}^{1 *}$

\begin{abstract}
Background: In several neuropathological conditions, microglia can become overactivated and cause neurotoxicity by initiating neuronal damage in response to pro-inflammatory stimuli. Our previous studies have shown that exposure to electromagnetic fields (EMF) activates cultured microglia to produce tumor necrosis factor (TNF)- $\alpha$ and nitric oxide (NO) through signal transduction involving the activator of transcription STAT3. Here, we investigated the role of STAT3 signaling in EMF-induced microglial activation and pro-inflammatory responses in more detail than the previous study.
\end{abstract}

Methods: N9 microglial cells were treated with EMF exposure or a sham treatment, with or without pretreatment with an inhibitor (Pyridone 6, P6) of the Janus family of tyrosine kinases (JAK). The activation state of microglia was assessed via immunoreaction using the microglial marker CD11b. Levels of inducible nitric oxide synthase (iNOS), TNF- $\alpha$ and NO were measured using real-time reverse transcription-polymerase chain reaction (RT-PCR), enzymelinked immunosorbent assay (ELISA) and the nitrate reductase method. Activation of JAKs and STAT3 proteins was evaluated by western blotting for specific tyrosine phosphorylation. The ability of STAT3 to bind to DNA was detected with an electrophoresis mobility shift assay (EMSA).

Results: EMF was found to significantly induce phosphorylation of JAK2 and STAT3, and DNA-binding ability of STAT3 in N9 microglia. In addition, EMF dramatically increased the expression of CD11b, TNF- $\alpha$ and iNOS, and the production of NO. P6 strongly suppressed the phosphorylation of JAK2 and STAT3 and diminished STAT3 activity in EMF-stimulated microglia. Interestingly, expression of CD11b as well as gene expression and production of TNF- $\alpha$ and iNOS were suppressed by P6 at 12 h, but not at $3 \mathrm{~h}$, after EMF exposure.

Conclusions: EMF exposure directly triggers initial activation of microglia and produces a significant proinflammatory response. Our findings confirm that the JAK2-STAT3 pathway may not mediate this initial microglial activation but does promote pro-inflammatory responses in EMF-stimulated microglial cells. Thus, the JAK2-STAT3 pathway might be a therapeutic target for reducing pro-inflammatory responses in EMF-activated microglia.

\section{Background}

The rapid development of society and technology has led to an unprecedented increase in the number and diversity of sources of electromagnetic fields (EMFs), including power lines, electric appliances, radio transmitters, and microwave sources. Numerous studies have

\footnotetext{
* Correspondence: yuzping@yahoo.com

+ Contributed equally

'Key Laboratory of Medical Protection for Electromagnetic Radiation Ministry of Education, Third Military Medical University, Chongqing 400038, China Full list of author information is available at the end of the article
}

investigated the effects of occupational or residential exposure to EMF, which has been identified as the fourth largest pollution hazard [1-7]. Several studies have suggested that biological systems exhibit a specific sensitivity to $2.45 \mathrm{GHz}$ microwaves (a water resonance frequency), which is widely used in household appliances, medical applications and communication systems. While some of these results have been difficult to reproduce, or have severe methodological shortcomings $[8,9]$, other studies have reported that occupational exposure

\section{Biomed Central}


to EMF may be associated with gliomas [10-12] or Alzheimer's disease [13-15]. Therefore, the effects of EMF exposure on the central nervous system (CNS) have been an active topic of investigation in recent years. Several studies have revealed strong glial reactivity in different parts of the brain after EMF exposure [16-19]. We have found activated microglia in the hippocampus and cortex of rats after exposure to EMF (unpublished results). In vivo animal experiments involving microglial activation, however, cannot clearly explain whether such activation is induced directly by EMF or indirectly as a consequence of neuronal injury from EMF exposure.

Microglia, the resident innate immune cells in the CNS, become activated in response to certain cues, such as brain injury and immunological stimuli [20,21]. Activated microglia undergo a dramatic morphological transformation. They then become motile and acquire a reactive profile that is characterized by proliferation, migration and phagocytosis [22-28]. Overactivated microglia can result in disastrous and progressive neurotoxic consequences, however, leading to excess production of factors such as superoxide [29], nitric oxide (NO) [30-32] and tumor necrosis factor- $\alpha$ (TNF- $\alpha)$ [33-36] that cause additional neuroinflammation [37-40]. Not surprisingly, activated microglia are important in the pathogenesis of neurodegenerative diseases, such as Alzheimer's disease [41], Parkinson's disease [42,43] and amyotrophic lateral sclerosis [44-46].

The signal transduction mechanisms involved in microglial activation and neuroinflammatory factors release after EMF exposure are still largely unknown. Microglia may be the principal target of the neurobiological effects of EMF. In response to extracellular stimuli, several major signaling pathways are upregulated in activated microglia. Several transcription factors, i.e., NF- $\kappa \mathrm{B}$, AP-1 and C/EBP, are involved in microglial activation in vivo and in vitro [47-49]. STAT signaling is another critical pathway that plays an important regulatory role in microglial reactivity to various stimuli, including cerebral ischemia, gangliosides, lipopolysaccharide, thrombin and cytokines [50-55]. We have previously shown that the JAK-STAT3 pathway is activated in EMF-stimulated microglia [56]. It is not known, however, whether JAKSTAT3 signaling triggers the initial activation of EMFstimulated microglia or whether it merely participates in the pro-inflammatory responses. Recently, a JAK inhibitor I (pyridone 6, P6), capable of producing complete inhibition of STAT3 activation, was shown to not alter the growth characteristics of tested cell lines even when used in a high $\mu \mathrm{M}$ range of concentrations. This observation suggests that persistent STAT3 inhibition with P6 may be a helpful tool in addressing the aforementioned questions.
Imbalanced microglial activation or hyperactivation can cause neurodegeneration, but the true initial trigger (s) of microglial activation has not been identified [57]. Furthermore, the role of the JAK-STAT signaling pathways in EMF-stimulated microglia has not yet been investigated. Hence, we exposed cultured N9 microglia to $2.45 \mathrm{GHz}$ electromagnetic fields and examined microglial activation, the release of pro-inflammatory factors, and the role of the JAK-STAT signaling pathway in this process.

\section{Methods}

\section{Cell culture}

The mouse microglial cell line N9 was a gift from Dr. Bai Yun (Department of Genetics, The Third Military Medical University, China) and was cultured as described in the original publications [58,59]. Briefly, cells were grown in Iscove's modified Dulbecco's medium (IMDM; HyClone, Logan, UT) supplemented with $5 \%$ heat-inactivated fetal bovine serum (FBS; HyClone), $2 \mathrm{mM}$ glutamine, $100 \mathrm{U} / \mathrm{ml}$ penicillin, $100 \mu \mathrm{g} / \mathrm{ml}$ streptomycin, and $50 \mu \mathrm{M}$ 2-mercaptoethanol (Sigma-Aldrich, St. Louis, MO). Cells were seeded in $25-\mathrm{cm}^{2} \mathrm{~T}$-flasks $\left(1 \times 10^{6}\right.$ cells/flask $)$ or 6 -well plates $\left(5 \times 10^{5}\right.$ cells/well $)$ at $37^{\circ} \mathrm{C}$ in a humidified $5 \% \mathrm{CO}_{2}$ atmosphere. The medium was exchanged for serum-free IMDM after $24 \mathrm{~h}$. Cells were then pretreated with or without P6 $(10 \mu \mathrm{M}$; Calbiochem, La Jolla, CA) or a solvent control (tissue culture grade dimethylsulfoxide (DMSO; SigmaAldrich)) for $1 \mathrm{~h}$ prior to EMF stimulation.

\section{Exposure system}

Pulsed EMF exposure was carried out in an anechoic chamber, and the ambient air temperature inside the anechoic chamber was $25-26^{\circ} \mathrm{C}$. Pulsed EMF was delivered through a rectangular horn antenna connected horizontally to a handset (Philips PM 7320X). The radiation was directed vertically downward toward the exposure flasks using a reflector. The microwave transmitter was operated at $2.45 \mathrm{GHz}$ at an average pulsed power of $90 \mathrm{~mW}$. The pulse width was $2 \mu \mathrm{s}$, and the pulse repetition rate was 500 pps. A 20 -min exposure to $2.45 \mathrm{GHz}$ pulsed microwaves at an average specific absorption rate (SAR) of $6 \mathrm{~W} / \mathrm{kg}$ was performed. During the 20 -min exposure period, the distance from the face of the antenna horn to the surface of the flasks where the cells were settled was $90 \mathrm{~cm}$. For EMF exposure, four flasks were placed into the upper chamber of a Perspex ${ }^{\text {Tw }}$ water bath $(24.5 \times 21 \mathrm{~cm})$. The temperature of the medium in the flasks in the upper chamber was maintained at $37^{\circ} \mathrm{C}$ by circulating heated water through the lower closed chamber. During sham exposure, four T-25 flasks were placed in the same conditions for the same period of time as the EMF-exposed group, except for the EMF 
exposure. Finite difference time domain (FDTD) analysis was performed to calculate the SAR value [60].

\section{Enzyme-linked immunosorbent assay (ELISA) of TNF- $\alpha$}

TNF- $\alpha$ release in cultured supernatants was determined using a mouse TNF- $\alpha$ ELISA kit (eBioscience, San Diego, CA). Briefly, ELISA plates (96-well; NUNC MaxiSorp, eBioscience) were coated with coating buffer $\left(100 \mu \mathrm{l} /\right.$ well), sealed and incubated overnight at $4^{\circ} \mathrm{C}$. The wells were washed 5 times with wash buffer and blocked with assay diluent at room temperature for $1 \mathrm{~h}$. The samples $(100 \mu \mathrm{l})$ collected from N9 cultures were added to each well and incubated overnight at $4^{\circ} \mathrm{C}$ for maximal sensitivity. Subsequently each plate was incubated with the detection antibody $(100 \mu \mathrm{l} /$ well $)$ diluted in assay buffer for $1 \mathrm{~h}$ and then avidin-HRP $(100 \mu \mathrm{l} /$ well) diluted in assay diluent for $30 \mathrm{~min}$ at room temperature. Each plate was subsequently incubated with tetramethylbenzidine (TMB) substrate solution for $15 \mathrm{~min}$; the reaction was stopped with $50 \mu \mathrm{l}$ of $2 \mathrm{~N}$ $\mathrm{H}_{2} \mathrm{SO}_{4}$ stop solution. The results were read using a microplate spectrophotometer at $540 \mathrm{~nm}$. A standard curve prepared from recombinant TNF- $\alpha$ was used to calculate the TNF- $\alpha$ production of the samples.

\section{Nitric oxide determination in culture medium}

$\mathrm{NO}$ was measured as released NO metabolites (nitrates and nitrites) using an NO detection kit (Nanjing Jiancheng Bioengineering Institute, Nanjing, CN). This method uses nitrate reductase to specifically reduce $\mathrm{NO}^{3-}$ to $\mathrm{NO}^{2-}$, and the content of $\mathrm{NO}^{2-}$ is determined colorimetrically. Briefly, $100 \mu \mathrm{l}$ of incubation medium and a standard were added to the wells. Then, $50 \mu \mathrm{l}$ of nicotinamide adenine dinucleotide (NADH) and nitrate reductase was added. After $30 \mathrm{~min}, 100 \mu \mathrm{l}$ of Greiss reagents I and II was added and incubated for $10 \mathrm{~min}$ at room temperature. The optical density of each well was determined using a microplate reader set at $540 \mathrm{~nm}$.

\section{Flow cytometry}

Expression of microglial marker CD11b [61] was measured by fluorescence-activated cell sorting (FACS) analysis to assess activation state of microglial cells. Briefly, after 20 min of EMF or sham exposure, microglial cells were washed three times with flow buffer (phosphatebuffered saline (PBS) containing $0.1 \%(\mathrm{w} / \mathrm{v})$ sodium azide and $1 \%(\mathrm{w} / \mathrm{v}) \mathrm{BSA})$ and re-suspended in $250 \mu \mathrm{l}$ of ice-cold flow buffer. Cells were pre-incubated with goat serum (Zhongshan Goldenbridge Biotechnology (Zsbio), Beijing, CN) for $20 \mathrm{~min}$ at $4^{\circ} \mathrm{C}$ to block non-specific binding to Fc receptors. Cells were then spun down at $5,000 \mathrm{rpm}$, washed three times with flow buffer, and incubated with rat anti-mouse monoclonal antibody CD11b (1:100; AbD Serotec, Oxford, UK) or rat IgG2b isotype control (1:100; AbD Serotec) for $1 \mathrm{~h}$ at $4^{\circ} \mathrm{C}$. Centrifugation and washing steps were repeated, and cells were then incubated with goat anti-rat IgGDyLight ${ }^{\circ} 49$ (1:200; AbD Serotec) for $1 \mathrm{~h}$ at $4^{\circ} \mathrm{C}$ in the dark. Quantitative analysis was performed using a FACSCalibur system (BD Biosciences, San Jose, CA).

\section{Confocal microscopy with double-label immunofluorescence}

As previously described [62], cultured cells were fixed and permeabilized. Cells were then pre-incubated with goat serum (Zsbio) for $20 \mathrm{~min}$ at room temperature and then washed 3 times with flow buffer. For immunofluorescence labeling, cell cultures were incubated with one of the following antibodies for $1 \mathrm{~h}$ at $37^{\circ} \mathrm{C}$ : rat antimouse monoclonal antibody CD11b (1:100; AbD Serotec) and rabbit anti-mouse monoclonal pTyr705-STAT3 antibodies (p-STAT3, 1:100; Cell Signaling Technology, Danvers, USA). For confocal microscopy of the doublelabeled samples, cell cultures were incubated simultaneously with goat anti-rat IgG-DyLight ${ }^{\circ} 549$ (1:200; AbD Serotec) and sheep anti-rabbit IgG-FITC (1:200; SigmaAldrich, St. Louis, USA) for $1 \mathrm{~h}$ at $37^{\circ} \mathrm{C}$ in the dark. Cell cultures were then washed and mounted with aqueous-based anti-fade mounting medium. Images of stained cells were captured using a Leica TCS-SP5 confocal laser scanning microscope (Leica, Mannheim, Germany). Image analysis was performed with a semiquantitative method. Fluorescence intensity was measured using software Image J 1.42 .

\section{Western blotting}

Cells were washed with ice-cold PBS and scraped in RIPA lysis buffer (Roche, Penzberg, Germany) containing protease inhibitors. Whole cell extracts ( $80 \mu \mathrm{g} / \mathrm{lane})$ were separated by $8 \%$ SDS PAGE under reducing conditions and then transferred onto nitrocellulose membranes (Millipore, Bedford, USA). The membranes were blocked with a special Odyssey blocking buffer (LI-COR, Lincoln, USA) for $3 \mathrm{~h}$ at room temperature. The proteins were detected by incubation at ambient temperature with monoclonal antibodies for p-STAT3 (1:1000; Cell Signaling Technology), STAT3 (1:1000; Cell Signaling Technology), phospho-JAK1 Tyr-1022/1023 (p-JAK1, 1:2000; Santa-Cruz Biotechnology, Santa Cruz, CA), JAK 1 (1:1000; Cell Signaling Technology), phospho-JAK2 Tyr-1007/1008 (p-JAK2, 1:2000; Santa-Cruz Biotechnology), and JAK2 (1:1000; Cell Signaling Technology) for $3 \mathrm{~h}$. Membranes were washed four times for 5 min each in tris-buffered saline Tween-20 (TBST) and then incubated with a fluorescently-labeled secondary antibody (1:5000, LI-COR) for $30 \mathrm{~min}$ at room temperature with gentle shaking. After the final washes with PBS, the signal was detected and quantified with the 
Odyssey infrared imaging system (LI-COR). Loading controls were detected with mouse monoclonal anti- $\beta$ actin antibody (1:5000, Sigma-Aldrich).

\section{Electrophoresis mobility shift assay (EMSA)}

The electrophoresis mobility shift assay (EMSA) for nucleoprotein extracts $(10 \mu \mathrm{g})$ was performed using the Odyssey Infrared EMSA Kit (LI-COR) according to the manufacturer's instructions. The following double-strand oligonucleotides were used as specific labeled probes or cold competitors: $5^{\prime}$-GAT CCT TCT GGG AAT TCC TAG ATC-3', 3'-CTA GGA AGA CCC TTA AGG ATC TAG-5'. Nuclear extract and STAT3 IRDye ${ }^{\mathrm{m}} 700$ infrared dye-labeled oligonucleotides (LI-COR) were incubated according to the manufacturer's instructions. The mixture was incubated for $30 \mathrm{~min}$ at $30^{\circ} \mathrm{C}$. Electrophoresis was performed at $10 \mathrm{~V} / \mathrm{cm}$ at $4^{\circ} \mathrm{C}$ using $5 \%$ native polyacrylamide gels. The gels were scanned with the Odyssey scan bed (LI-COR).

\section{Reverse transcription-polymerase chain reaction (RT-PCR)}

Total RNA was isolated using Trizol $(1 \mathrm{ml} /$ well; Roche, Penzberg, DE) from 6-well plates according to the manufacturer's protocol. The integrity of the RNA sample was confirmed with gel electrophoresis and by reverse transcription-PCR using primers for housekeeping genes. Moloney murine leukemia virus (MMLV) reverse transcriptase (Toyobo, Tokyo, Japan) was used to convert $1 \mu \mathrm{g}$ of total RNA into cDNA at $42^{\circ} \mathrm{C}$. The RT-PCR exponential phase was determined to be 20-32 cycles for semiquantitative comparisons. $\beta$ Actin was measured as a loading control. The amplification of cDNA was performed with the following primers: mouse $\boldsymbol{\beta}$-actin [GenBank: 007393.2]: forward 5'-TAAAGACCTCTATGCCAACACAGT-3'; reverse 5'-CACGATGGAGGGGCCGGACTCATC-3'. iNOS [GenBank: 010927.2]: forward 5'-AACTGTAGCACAGCACAGGAAA-3'; reverse 5'-ACAAGATCAGGAGGGATTTCAA-3'. TNF- $\boldsymbol{\alpha}$ [GenBank: 013693.2]: forward 5'-GCCTATGTCTCAGCCTCTTCTC-3'; reverse 5'GGAGGTTGACTTTCTCCTGGTA-3'. The amplification reaction was carried out in a Perkin-Elmer GeneAmp (Perkin Elmer, Boston, USA). The resulting PCR products were separated in $1.5 \%$ agarose gels and visualized with ethidium bromide staining. For semiquantitative evaluation, densitometric analysis was performed using Quantity One software (Bio-Rad, Hercules, USA).

\section{Statistical analysis}

Data are presented as the mean of each treatment group \pm standard deviation of the mean (SD). Statistical differences between the groups were assessed by one-way analysis of variance (ANOVA) followed by Duncan's Multiple Range test. Statistical significance was established at $\mathrm{P}<0.05$ unless otherwise indicated.

\section{Results}

Effect of EMF exposure on CD11b expression in N9 cells

It has been previously suggested that activated microglia express different proteins and surface markers. Of these, CD11b has the greatest biological significance $[63,64]$. Because increased expression of CD11b is a typical feature of microglial activation [65], we assessed the effect of EMF exposure on the expression of CD11b in N9 cells by FACS and confocal microscopy. EMF was found to significantly increase CD11b expression (Figure 1 \&2I). Figure 1 clearly shows increases in CD11b expression by N9 cells $3 \mathrm{~h}$ and $12 \mathrm{~h}$ after EMF exposure (red line). A similar pattern was observed with immunolocalization and confocal microscopy. Immunofluorescence reaction was significantly increased $12 \mathrm{~h}$ after EMF exposure (Figure 2I). In contrast, no increase in $\mathrm{CD} 11 \mathrm{~b}$ expression was observed in the sham-exposure control groups (Figure 1, 2C \&2F).

\section{Effect of EMF exposure on TNF- $\alpha$, iNOS expression and NO release from N9 cells}

Given the pro-inflammatory effect of EMF exposure on microglia, we measured levels of TNF- $\alpha$ and iNOS, and the resulting NO production, in cell culture medium supernatants at the indicated times after EMF exposure. As shown in Figure 3A, EMF exposure significantly induced expression of TNF- $\alpha$ and iNOS. RT-PCR analysis showed that the levels of TNF- $\alpha$ and iNOS mRNA peaked at $3 \mathrm{~h}$ and $6 \mathrm{~h}$, respectively, and were sustained up to $24 \mathrm{~h}$ after EMF exposure (Figure 3B). Because iNOS is an inducible enzyme, we examined its activity by measuring the amount of nitrite converted from $\mathrm{NO}$ in the medium using a Griess reagent. Release of NO was found to peak at $6 \mathrm{~h}$ and to remain high up to $24 \mathrm{~h}$ after EMF exposure (Figure 3D). Next, the secretion of TNF- $\alpha$ was measured by ELISA. Production of TNF- $\alpha$ reached its first peak at $3 \mathrm{~h}$, gradually decreased, peaked again at $12 \mathrm{~h}$ and was then sustained for up to $24 \mathrm{~h}$ after EMF exposure (Figure 3C).

\section{Effect of EMF exposure on phosphorylation and DNA- binding activity of STAT3 in N9 cells}

In previous work, we have shown that activation of JAKs and STAT3 is involved in EMF-activated microglia [56]. To further determine the timing of STAT3 activation in EMF-stimulated microglia, we studied the immunolocalization, phosphorylation and DNA-binding activity of STAT3 at the indicated times. EMF exposure was found to result in strongly phosphorylated STAT3 in a timedependent manner, with the peak activation occurring at $12 \mathrm{~h}$ (Figure 4A). The total amount of STAT3 did not change in response to EMF emission. Immunolocalization 


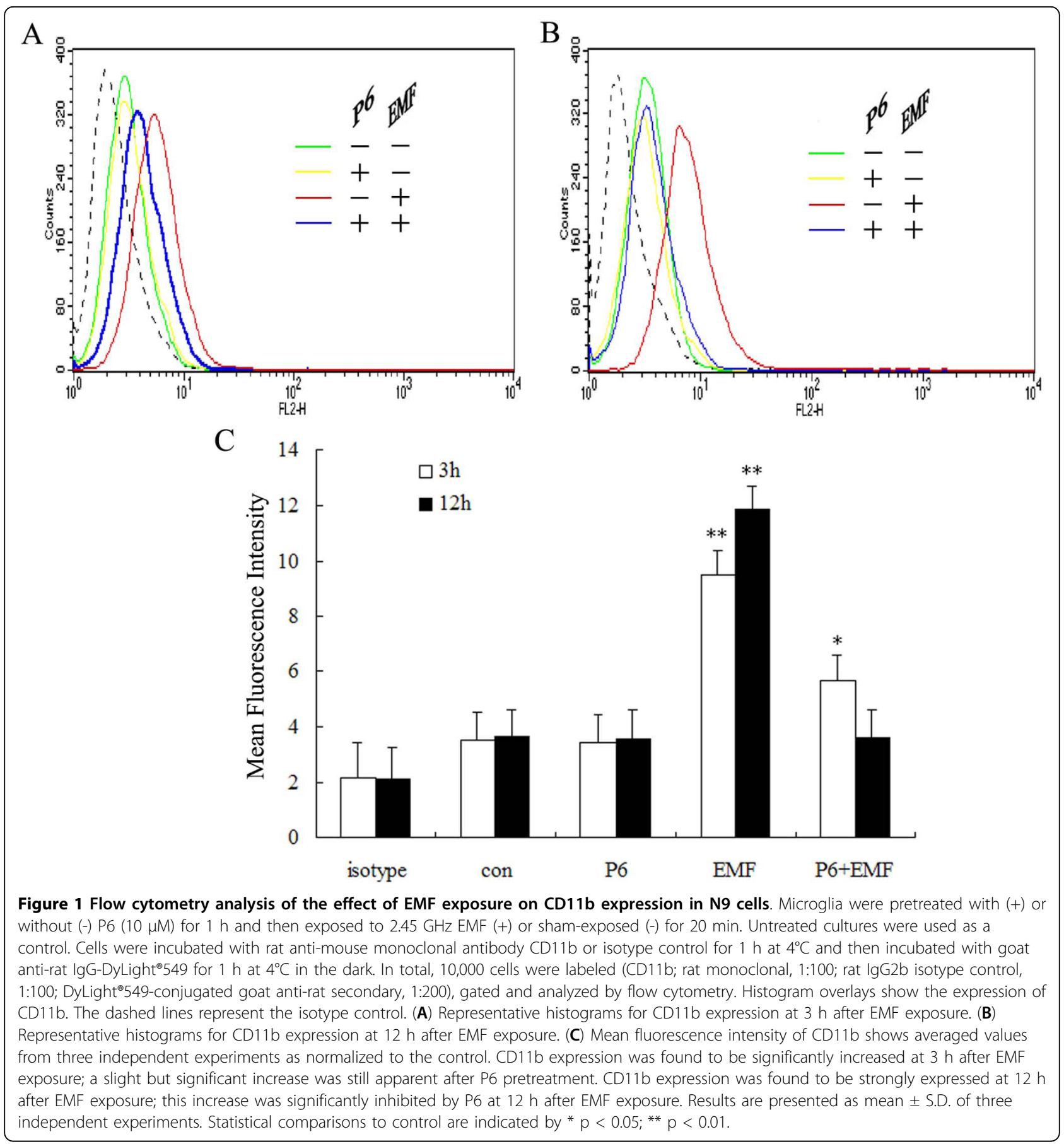

and confocal microscopy provided further evidence for STAT3 phosphorylation, showing a strong increase in fluorescence intensity in N9 cells at $12 \mathrm{~h}$ after EMF exposure (Figure 2G). In contrast, a low level of STAT3 phosphorylation was observed in the untreated $(0 \mathrm{~h})$ group (Figure 2A \&4A).

Under basal conditions, STATs are located in the cytoplasm; however, when these transcription factors become phosphorylated, they translocate to the nucleus within minutes [66]. Accordingly, we performed gel mobility shift assays to analyze the ability of STAT3 to bind DNA. Figure $4 \mathrm{C}$ shows a specific DNA-protein complex that is slightly apparent at $1 \mathrm{~h}$ after EMF exposure, more fully apparent at $3 \mathrm{~h}$ and peaks at $12 \mathrm{~h}$ after EMF exposure. No protein-DNA complex formation was observed in the control group. The following experiments with the JAK inhibitor P6 were performed at the 3 and $12 \mathrm{~h}$ points. 

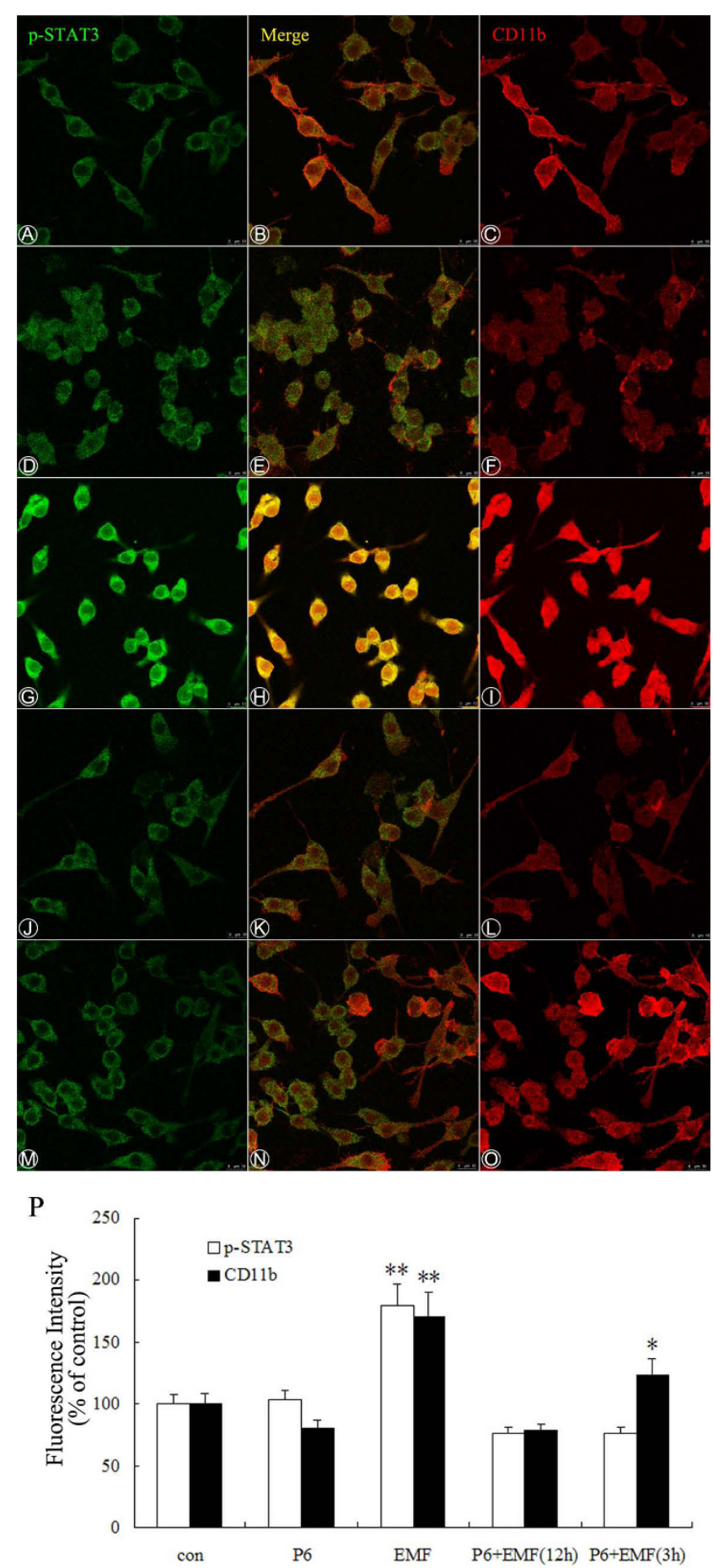

Figure 2 Localization of CD11b and p-STAT3 immunoreactivity in activated N9 cells. Experiments were performed as described above. Confocal immunofluorescence microscopy was performed on cultures that were immunoreacted with antibodies against phospho-STAT3 tyr705 (left, rabbit monoclonal, 1:100; FITC-conjugated sheep anti- rabbit secondary, 1:200) and CD11b (right, as Figure 1 shows) at $12 \mathrm{~h}$ after EMF exposure (A-L). (A-C) Untreated cultures were used as a control. (D-F) Cultures pretreated with P6 (10 $\mu \mathrm{M})$. (G-I) EMF induced more phosphorylation of STAT3 (green) and expression of CD11b (red) in N9 cells. (J-L) P6 inhibits the phosphorylation of STAT3 and expression of CD11b at $12 \mathrm{~h}$ after EMF exposure. (M-O) P6 pretreatment significantly suppresses the phosphorylation of STAT3, but a slight and significant increase of CD11b is still apparent at $3 \mathrm{~h}$ after EMF exposure. Scale bar $10 \mu \mathrm{m}$. (P) Bar graphs show semi-quantification of fluorescence intensity for p-STAT3 and CD11b in N9 cells. Results are presented as mean \pm S.D. of three independent experiments. Statistical comparisons to control are indicated by ${ }^{*} p<0.05 ;{ }^{*} p<0.01$. 

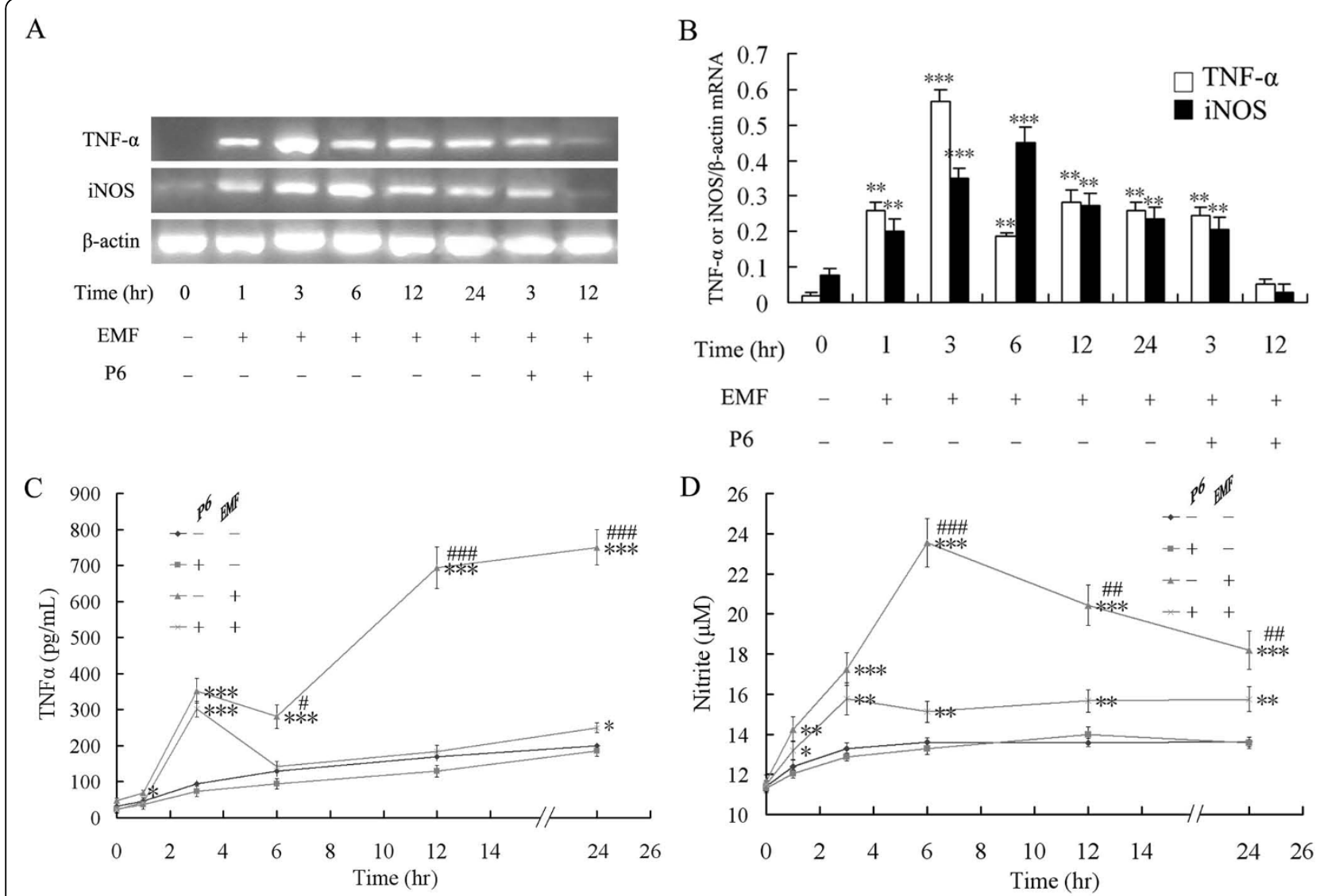

Figure 3 EMF exposure induces TNF- $\alpha$ and iNOS expression and NO release from N9 cells. Experiments were performed as described above. (A) RT-PCR analysis showing that EMF exposure significantly induces the mRNA expression of TNF- $\alpha$ and iNOS. (B) Mean \pm S.D. of mRNA levels from five pooled samples per time point. (C) The concentration of TNF- $\alpha$ in the medium was determined by ELISA after cells were treated at the indicated time points. (D) The amount of nitrite was determined by the Griess reaction. Results are presented as the mean \pm S.D. of five independent experiments. Statistical comparisons to control are indicated by ${ }^{*} p<0.05 ;{ }^{*} p<0.01 ;{ }^{* * *} p<0.001$. Statistical comparisons between EMF treatment group and P6 preconditioning are indicated by \# $p<0.05$; \#\# $p<0.01$; \#\#\# $p<0.001$.

\section{Effect of EMF exposure on JAK1 and JAK2 phosphorylation in $\mathrm{N} 9$ cells}

Given the above results, we focused our studies on the upstream tyrosine kinases of the STAT3 signaling molecule, i.e., the JAKs [67], and performed a time course study of the phosphorylation of JAKs in EMFstimulated N9 microglia. Western blots showed dramatic phosphorylation of JAK2 but not JAK1 in N9 cells at 1, 3, 6, 12 and $24 \mathrm{~h}$ after EMF exposure (Figure $5)$. Figure 5B shows a low level of JAK1 phosphorylation that occurred immediately at $1 \mathrm{~h}$ after EMF exposure; JAK1 phosphorylation subsequently returned to basal levels. In contrast, phosphorylation of JAK2 was found to increase over a period of several hours, showing kinetics similar to those of STAT3 phosphorylation (Figure 5C). JAK2 phosphorylation was also apparent at low levels in the control group. The total amount of JAK1 and JAK2 did not change in response to EMF stimulation.
Inhibitory effect of P6 on EMF-induced CD11b, TNF- $\alpha$ and iNOS expression and NO release

To further assess the potential role of the JAK2-STAT3 pathway in EMF-induced activation and pro-inflammatory responses of N9 microglia, we examined whether the JAK inhibitor P6 could affect EMF-induced increase of TNF- $\alpha$, iNOS and NO, and the initial activation of microglia. Western blot analysis and EMSA experiments show that P6 preconditioning completely blocks activation of JAK2 and STAT3 at 3 and $12 \mathrm{~h}$ after EMF exposure (Figure $4 \& 5$ ). Our results also show that P6 preconditioning reduces $\mathrm{CD} 11 \mathrm{~b}$ expression (Figure $1 \mathrm{~B}$ $\& 2 \mathrm{~L}$ ), decreases expression of iNOS and TNF- $\alpha$, and blocks NO release at $12 \mathrm{~h}$ after EMF exposure (Figure 3 ). Interestingly, the fluorescence intensity of CD11b was found to still be significantly increased at $3 \mathrm{~h}$ after EMF exposure even with P6 preconditioning (Figure 1A, 2O). In addition, P6 preconditioning was found to have a slight inhibitory effect on TNF- $\alpha$ and iNOS mRNA 


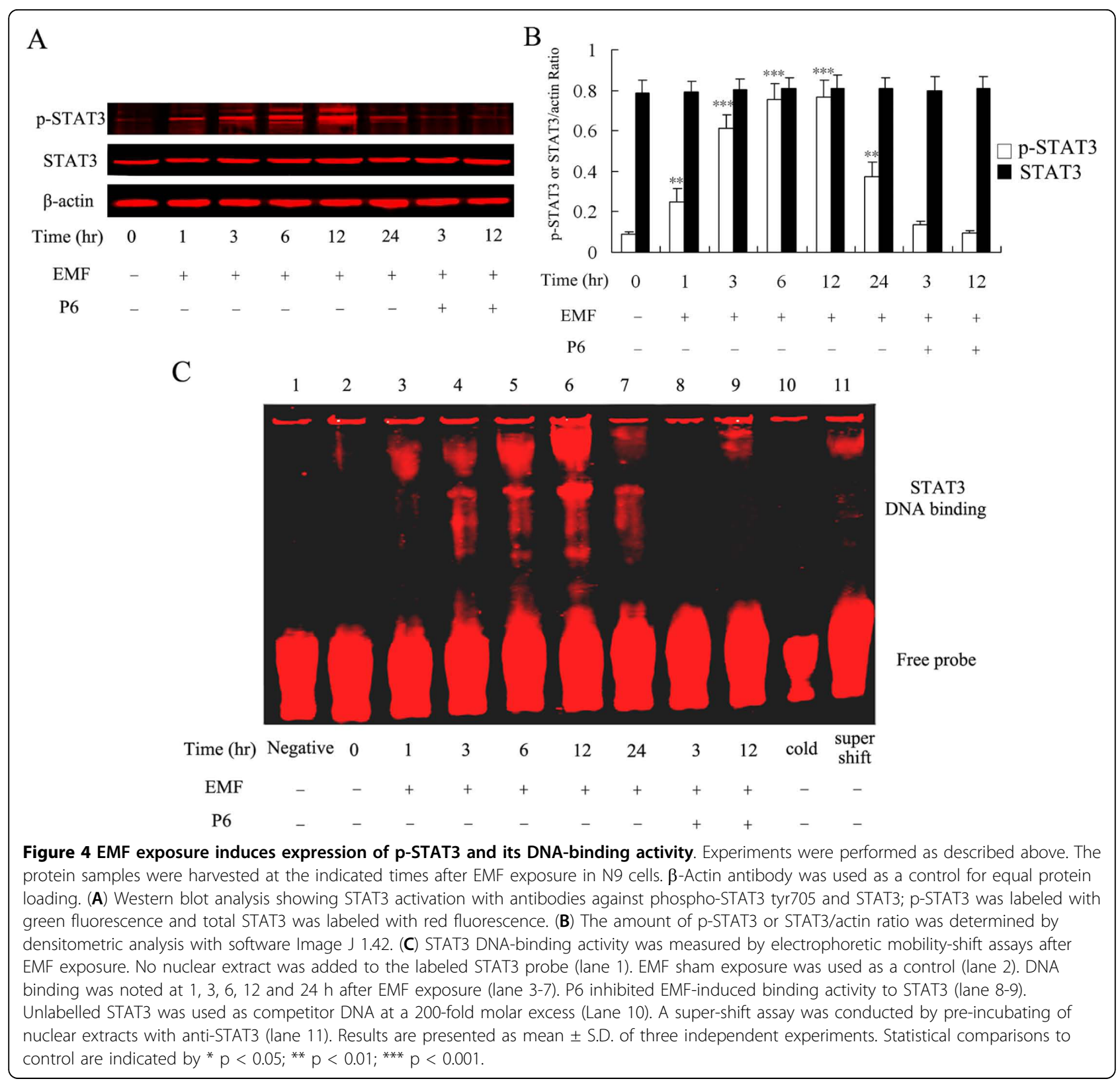

expression or protein synthesis at $3 \mathrm{~h}$ after EMF exposure (Figure 3).

\section{Discussion}

In the present study, we observed N9 microglial activation and pro-inflammatory responses after EMF exposure. We found that the JAK2-STAT3 pathway is activated in EMFstimulated N9 microglial cells. The activation of microglia and the secretion of pro-inflammatory factors were significantly reduced by P6 treatment at $12 \mathrm{~h}$ after EMF exposure, while $\mathrm{P} 6$ preconditioning did not inhibit the above processes at $3 \mathrm{~h}$ post exposure. Our data suggest that the JAK2-STAT3 pathway may play a pivotal role in the pro-inflammatory response but not in the initial activation of microglia after EMF exposure.

It has been reported that increased CD11b expression corresponds to extent of microglial activation $[63,64,68]$. Here, we observed a dramatic increase in CD11b expression in an in vitro model exposing N9 cells to $2.45 \mathrm{GHz}$ using a waveguide system that simulates occupational or residential exposure, at a specific absorption rate (SAR) of $6 \mathrm{~W} / \mathrm{kg}$. This result suggests that EMF may potentially affect microglial activation. Our data are consistent with earlier findings demonstrating increased glial reactivity in a model using about $900 \mathrm{MHz}$ from a global system for mobile communication, at a high SAR of 6 


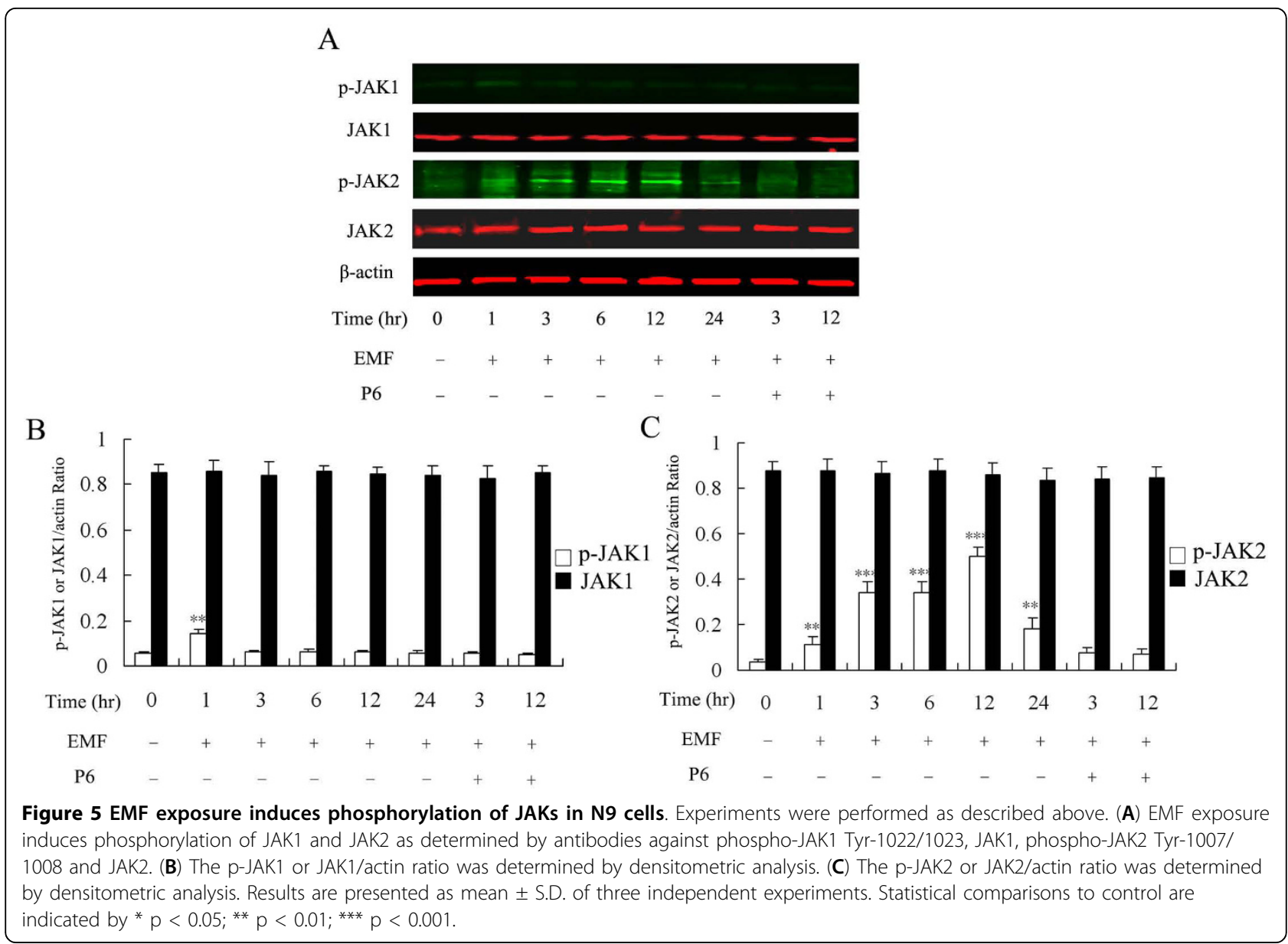

$\mathrm{W} / \mathrm{kg}[17,18,69]$. Other investigators, however, have argued that EMF exposure does not lead to microglial activation at low SAR values simulating either microwave radiation or mobile telephone radiofrequency fields [70-72]. Taken together, these studies show microglial reactivity only in model systems with high SAR values of up to $6 \mathrm{~W} / \mathrm{kg}$. Thus, we consider that high-energy EMF, with definite thermal effects [73], could potentially induce microglial activation.

Microglia are known to be exquisite sensors of even minor pathological changes in the CNS $[28,61]$. They also act as active contributors to neuronal damage in neurodegenerative diseases such as Alzheimer's disease, Parkinson's disease and HIV dementia [74,75]. An increasing amount of evidence suggests that migroglia are key factors in the process of neuroinflammation [74]. Microglia-induced neuronal injury may be mediated by the production of TNF- $\alpha, \mathrm{NO}$, and reactive oxygen species [76-78]. Our results confirm significant up-regulation of TNF- $\alpha$ and iNOS mRNA, and release of the pro-inflammatory factors TNF- $\alpha$ and NO, in N9 microglia after EMF exposure. These results suggest that EMF, as an external physical factor, could facilitate microglia pro-inflammatory responses through the secretion of pro-inflammatory factors. This activity may ultimately contribute to CNS impairment or disease.

It is well known that microglia monitor the external environment [61] and respond to external stimuli [79] via signaling cascades that allow them to perturb membrane function and trigger the activation of one or more intracellular signaling pathways [75]. In contrast, there is a lack of information regarding signal transduction mechanisms and molecular targets of EMF-activated microglia. Here, our time course experiments show different expression levels of the JAK-STAT pathway in EMF-activated microglia. It has been demonstrated that the JAK-STAT cascade plays an essential role in driving a variety of immune responses in glial cells in the brain $[54,80]$. Different expression levels of the JAK-STAT pathway have been detected in glial cells in the brain [51-53,76,80-82] and associated with pathological CNS conditions such as cerebral ischemia[52,55,83], traumatic brain injury $[84,85]$ and brain inflammation [86]. These observations suggest that EMF exposure likely affects microglial activation through the activation of the JAK-STAT pathway. 
To investigate the potential function of the JAK-STAT pathway in EMF-activated microglia, we next examined whether the JAK inhibitor P6 could affect the EMFinduced increases of TNF- $\alpha$, iNOS, NO and CD11b. P6 can effectively block the activation of JAK1, JAK2 and STAT3 $[87,88]$. Our results revealed that the activation of JAK2 increased with kinetics similar to those of phosphorylated-STAT3. The activation of JAK2 and STAT3 was significantly inhibited by P6 at 3 and $12 \mathrm{~h}$ after EMF exposure. These results provide further evidence that JAK2-STAT3 signaling plays a role in the reactivity of EMF-stimulated microglia.

Most previous studies have shown that the JAK-STAT signaling pathway is involved in microglial activation [50-55]. In our study, the activation of microglia, the transcription of TNF- $\alpha$ and iNOS, and the secretion of TNF- $\alpha$ and NO were not significantly inhibited at $3 \mathrm{~h}$ by $\mathrm{P} 6$ in EMF-activated microglia, however. These results suggest that the JAK2-STAT3 pathway may not mediate the initial activation of microglia after EMF exposure. Other signaling pathways may be involved in this process. Chang et al.[89] reported that microglial inactivation by ketamine is at least partially due to the inhibition of ERK1/2 phosphorylation. Ryu et al. [90] reported that thrombin induces $\mathrm{NO}$ release from cultured rat microglia via protein kinase $\mathrm{C}$, mitogenactivated protein kinase, and NF-kappa B. Thus, we speculate that EMF exposure activates microglia through other signaling pathways.

It has been demonstrated that activated microglia secrete a diverse range of pro-inflammatory and neurotoxic factors such as superoxide, TNF- $\alpha$, interleukin (IL)-1 $\beta$, IL- 6 and NO [74]. The cytokines IL- $1 \beta$ and TNF- $\alpha$, as mentioned above, may stimulate microglia to produce monocyte chemoattractant protein (MCP)-1, macrophage inflammatory protein (MIP)- $1 \alpha$, and MIP$1 \beta$, which also may contribute to neuroinflammation [91]. After becoming activated by cytokines, microglia also release more cytokines into the extracellular space, thus forming an autocrine loop with positive feedback between microglial activation and cytokine production. This loop could explain the maintenance of microglial activation and the enhancement of pro-inflammatory responses for $24 \mathrm{~h}$ after EMF exposure. Several reports have reported that STAT3 acts as a transcription factor in modulating cytokine-induced pro- and anti-inflammatory responses [92,93]. Recently, Tanabe et al. [94] reported that TNF- $\alpha$ induces IL-6 synthesis through the JAK/STAT3 pathway in rat C6 glioma cells. Mir et al. [95] indicated that the enhancing effect of TNF- $\alpha$ on IFN- $\gamma$ induced iNOS/NO generation is dependent on the JAK-STAT signaling pathway. In this study, P6 was found to reduce $\mathrm{CD} 11 \mathrm{~b}$ expression, decrease the expression of TNF- $\alpha$ and iNOS, and relieve the release of
TNF- $\alpha$ and NO at $12 \mathrm{~h}$ in EMF-activated microglia. Our data suggest that a feedback loop may be formed to maintain the activation of microglia and extend the proinflammatory responses through the JAK2-STAT3 pathway. Based on these data, we hypothesize that after EMF exposure: (i) there might be some other signaling pathway that rapidly activates microglia; (ii) pro-inflammatory factors secreted by activated microglia may activate the JAK-STAT pathway; and (iii) the activated JAK-STAT signaling pathway may further induce release of pro-inflammatory factors and maintain the activation of microglia.

We studied the effects of EMF exposure on cultured N9 microglial cells and demonstrate that an initial activation of microglia is induced by EMF exposure. In addition, many other physical factors such as infrasound exposure, irradiation, heat shock treatment and hyperthermia, can stimulate activation and pro-inflammatory reactions of microglia [96-100]. The transmembrane signal transduction mechanisms of microglial activation in these physical environments remain poorly understood. Further investigations into these transmembrane signal transduction mechanisms may help to protect humans against electromagnetic radiation, ionizing radiation and other hazardous physical factors.

\section{Conclusions}

Our results strongly suggest that external electromagnetic emission as a physical stimulation directly triggers an initial activation of microglia and produces significant pro-inflammatory responses. Activation of JAK2-STAT3 signaling occurs in parallel with the microglial activation and the release of pro-inflammatory factors. Microglial activation and pro-inflammatory responses are significantly reduced by P6 at $12 \mathrm{~h}$, but not at $3 \mathrm{~h}$, after EMF exposure. These results suggest that the JAK2-STAT3 pathway may not mediate the initial microglial activation, but does promote pro-inflammatory responses in EMF-stimulated microglial cells. Our results provide a basis to determine whether the pro-inflammatory responses of EMF-stimulated microglia can be suppressed by inhibition of the JAK2-STAT3 pathway in therapeutic interventions.

\section{List of abbreviations}

EMF: Electromagnetic fields; NO: nitric oxide; TNF- $\alpha$ : tumor necrosis factor- $\alpha$; JAK-STAT: Janus kinase-signal transducers and activators of transcription; iNOS: inducible NO synthase; P6: Pyridone 6; FACS: fluorescence activated cell sorting; EMSA: electrophoresis mobility shift assay; ELISA: enzyme-linked immunosorbent assay.

\section{Acknowledgements}

Sources of support: This work was supported by the National Natural Science Foundation of China (Nos. 30470418 and 30970672). The authors gratefully acknowledge Fang Wang, Wenjing Luo, Maohua Hu and Liting Wang for their skillful technical assistance. 


\section{Author details}

'Key Laboratory of Medical Protection for Electromagnetic Radiation Ministry of Education, Third Military Medical University, Chongqing 400038, China. ${ }^{2}$ Institute of Tropical Medicine, Third Military Medical University, Chongqing 400038, China. ${ }^{3}$ International Travel Healthcare Center, Chongqing Entry-Exit Inspection and Quarantine Bureau, Chongqing 401147, China.

\section{Authors' contributions}

This study is based on an original idea of XSY. XSY and GLH wrote the manuscript. XSY and MQL carried out the FACS and confocal double-label immunofluorescence assays. GLH, YTH, CHC carried out the RT-PCR, western blotting and EMSA assays. YW carried out some mediator assays. GBZ provided EMF exposure system. All authors have read and approved the final manuscript.

\section{Competing interests}

The authors declare that they have no competing interests.

Received: 2 July 2010 Accepted: 9 September 2010

Published: 9 September 2010

\section{References}

1. Borbély AA, Huber R, Graf T, Fuchs B, Gallmann E, Achermann P: Pulsed high-frequency electromagnetic field affects human sleep and sleep electroencephalogram. Neurosci Lett 1999, 275:207-210.

2. Koivisto $M$, Krause $C M$, Revonsuo $A$, Laine $M$, Hämäläinen $H$ : The effects of electromagnetic field emitted by GSM phones on working memory. Neuroreport 2000, 11:1641-1643.

3. Huber R, Treyer V, Borbély AA, Schuderer J, Gottselig JM, Landolt HP, Werth E, Berthold T, Kuster N, Buck A, Achermann P: Electromagnetic fields, such as those from mobile phones, alterregional cerebral blood flow and sleep and waking EEG. J Sleep Res 2002, 11:289-295.

4. Maier R, Greter SE, Maier N: Effects of pulsed electromagnetic fields on cognitive processes - a pilot study on pulsed field interference with cognitive regeneration. Acta Neurol Scand 2004, 110:46-52.

5. Besset A, Espa F, Dauvilliers Y, Billiard M, de Seze R: No effect on cognitive function from daily mobile phone use. Bioelectromagnetics 2005 26:102-108.

6. Terao $\mathrm{Y}$, Okano T, Furubayashi T, Ugawa Y: Effects of thirty-minute mobile phone use on visuo-motor reaction time. Clin Neurophysiol 2006, 117:2504-2511.

7. Furubayashi T, Ushiyama A, Terao Y, Mizuno Y, Shirasawa K, Pongpaibool P, Simba AY, Wake K, Nishikawa M, Miyawaki K, Yasuda A, Uchiyama M, Yamashita HK, Masuda H, Hirota S, Takahashi M, Okano T, Inomata-Terada S, Sokejima S, Maruyama E, Watanabe S, Taki M, Ohkubo C, Ugawa Y: Effects of short-term W-CDMA mobile phone base station exposure on women with or without mobile phone related symptoms. Bioelectromagnetics 2009, 30:100-113.

8. Diem E, Schwarz C, Adlkofer F, Jahn O, Rüdiger H: Non-thermal DNA breakage by mobile-phone radiation $(1800 \mathrm{MHz})$ in human fibroblasts and in transformed GFSH-R17 rat granulosa cells in vitro. Mutat Res 2005, 583:178-183.

9. Vijayalaxmi, McNamee JP, Scarfi MR: Comments on: "DNA strand breaks" by Diem et al. [Mutat. Res. 583 (2005) 178-183] and Ivancsits et al. [Mutat. Res.583 (2005) 184-188]. Mutat Res 2006, 603:104-106.

10. Schüz J, Böhler E, Berg G, Schlehofer B, Hettinger I, Schlaefer K, Wahrendorf J, Kunna-Grass K, Blettner M: Cellular phones, cordless phones, and the risk of glioma and meningioma (Interphone study group, Germany). Am J Epidemiol 2006, 163:512-520.

11. Hepworth SJ, Schoemaker MJ, Muir KR, Swerdlow AJ, van Tongeren MJ, McKinney PA: Mobile phone use and risk of glioma in adults: casecontrol study. BMJ 2006, 332:883-887.

12. Deltour I, Johansen C, Auvinen A, Feychting M, Klaeboe L, Schüz J: Time Trends in Brain Tumor Incidence Rates in Denmark, Finland, Norway, and Sweden, 1974 - 2003. J Natl Cancer Inst 2009, 101:1721-1724. Hardell L, Carlberg M. Mobile phones, cordless phones and the risk for brain tumours. Int J Oncol 2009, 35:5-17.

13. Sobel E, Davanipour Z, Sulkava R, Erkinjuntti T, Wikstrom J, Henderson WW, Buckwalter G, Bowman JD, Lee PJ: Occupations with Exposure to Electromagnetic Fields: A Possible Risk Factor for Alzheimer's Disease. Am J Epidemiol 1995, 142:515-524.
14. Sobel E, Dunn M, Davanipour Z, Qian Z, Chui HC: Elevated risk of Alzheimer's disease among workers with likely electromagnetic field exposure. Am Acad Neurol 1996, 47:1477-1481.

15. Garcla AM, Sisternas A, Hoyos SP: Occupational exposure to extremely low frequency electric and magnetic fields and Alzheimer disease: a meta-analysis. Int J Epidemiol 2008, 37:329-340.

16. Fritze K, Wiessner C, Kuster N, Sommer C, Gass P, Hermann DM, Kiessling M, Hossmann KA: Effect of global system for mobile communication microwave exposure on the genomic response of the rat brain. Neuroscience 1997, 81:627-639.

17. Mausset-Bonnefont AL, Hirbec $H$, Bonnefont X, Privat A, Vignon J, de Sèze R: Acute exposure to GSM 900-MHz electromagnetic fields induces glial reactivity and biochemical modifications in the rat brain. Neurobiol dis 2004, 17:445-454

18. Brillaud E, Piotrowski A, de Seze R: Effect of an acute $900 \mathrm{MHz}$ GSM exposure on glia in the rat brain: A time-dependent study. Toxicol 2007, 238:23-33

19. Ammari M, Brillaud E, Gamez C, Lecomte A, Sakly M, Abdelmelek H, de Seze R: Effect of a chronic GSM $900 \mathrm{MHz}$ exposure on glia in the rat brain. Biomed Pharmacother 2008, 62:273-281.

20. Nimmerjahn A, Kirchhoff F, Helmchen F: Resting microglial cells are highly dynamic surveillants of brain parenchyma in vivo. Science 2005, 308:1314-1318.

21. Fetler $L$, Amigorena S: Neuroscience. Brain under surveillance: the microglia patrol. Science 2005, 309:392-393.

22. Upender MB, Naegele JR: Activation of microglia during developmentally regulated cell death in the cerebral cortex. Dev Neurosci 1999, 21:491-505.

23. Streit WJ: Microglia as neuroprotective, immunocompetent cells of the CNS. Glia 2002, 40:133-139.

24. Liao H, Bu WY, Wang TH, Ahmed S, Xiao ZC: Tenascin-R plays a role in neuroprotection via its distinct domains coordinate to modulate the microglia function. J Biol Chem 2004, 280:8316-8323.

25. Harry GJ, McPherson CA, Wine RN, Atkinson K, Lefebvre d'Hellencourt C: Trimethyltin-induced neurogenesis in the murine hippocampus. Neurotox Res 2004, 5:623-627.

26. Town $T$, Nikolic $V$, Tan J: The microglial 'activation' continuum: from innate to adaptive responses. J Neuroinflammation 2005, 2:24.

27. Garden GA, Moller T: Microglia biology in health and disease. $J$ Neuroimmune Pharmacol 2006, 1:127-137.

28. Hanisch UK, Kettenmann H: Microglia: active sensor and versatile effector cells in the normal and pathologic brain. Nature Neurosci 2007, 10:1387-1394.

29. Colton CA, Gilbert DL: Production of superoxide anions by a CNS macrophage, the microglia. FEBS Lett 1987, 223:284-288.

30. Ii $M$, Sunamoto $M$, Ohnishi K, Ichimori Y: $\beta$-amyloid protein-dependent nitric oxide production from microglial cells and neurotoxicity. Brain Res 1996, 720:93-100.

31. Moss DW, Bates TE: Activation of murine microglial cell lines by lipopolysaccharide and interferon- $\gamma$ causes NO-mediated decreases in mitochondrial and cellular function. Eur J Neurosci 2001, 13:529-538.

32. Liu B, Gao HM, Wang JY, Jeohn GH, Cooper CL, Hong JS: Role of nitric oxide in inflammation-mediated neurodegeneration. Ann NY Acad SCi 2002, 962:318-331.

33. Sawada M, Kondo N, Suzumura A, Marunouchi T: Production of tumor necrosis factor- $\alpha$ by microglia and astrocytes in culture. Brain Res 1989, 491:394-397.

34. Lee SC, Liu W, Dickson DW, Brosnan CF, Berman JW: Cytokine production by human fetal microglia and astrocytes. Differential induction by lipopolysaccharide and IL-1 $\beta$. J Immunol 1993, 150:2659-2667.

35. Griffin WS, Sheng JG, Royston MC, Gentleman SM, McKenzie JE, Graham DI, Roberts GW, Mrak RE: Glial-neuronal interactions in Alzheimer's disease: the potential role of a 'cytokine cycle' in disease progression. Brain Pathol 1998, 8:65-72.

36. Dheen ST, Jun Y, Yan Z, Tay SS, Ang Ling E: Retinoic acid inhibits expression of TNF- $\alpha$ and iNOS in activated rat microglia. Glia 2005, 50:21-31.

37. Tichauer J, Saud K, von Bernhardi R: Modulation by astrocytes of microglial cell-mediated neuroinflammation: effect on the activation of microglial signaling pathways. Neuroimmunomodulation 2007, 14:168-174. 
38. Harry GJ, Kraft AD: Neuroinflammation and microglia: considerations and approaches for neurotoxicity assessment. Expert Opin Drug Metab Toxicol 2008, 4:1265-1277.

39. Venneti S, Wiley CA, Kofler J: Imaging microglial activation during neuroinflammation and Alzheimer's disease. J Neuroimmune Pharmacol 2009, 4:227-243.

40. Ock J, Han HS, Hong SH, Lee SY, Han YM, Kwon BM, Suk K: Obovato attenuates microglia-mediated neuroinflammation by modulating redox regulation. Br J Pharmacol 2010, 159:1646-1662.

41. Mhatre M, Floyd RA, Hensley K: Oxidative stress and neuroinflammationin Alzheimer's disease and amyotrophicl ateral sclerosis: common links and potential therapeutic targets. J Alzheimer's Dis 2004, 6:147-157.

42. Tansey MG, McCoy MK, Frank-Cannon TC: Neuroinflammatory mechanisms in Parkinson's disease: potential environmental triggers, pathways, and targets for early therapeutic intervention. Exp Neurol 2007, 208:1-25.

43. Whitton PS: Inflammation as a causative factor in the aetiology of Parkinson's disease. Br J Pharmacol 2007, 150:963-976.

44. McGeer PL, McGeer EG: Inflammatory processes in amyotrophic lateral sclerosis. Muscle Nerve 2002, 26:459-470.

45. Sargsyan SA, Monk PN, Shaw PJ: Microglia as potential contributors to motor neuroninjury in amyotrophic lateral sclerosis. Glia 2005, 51:241-253.

46. Weydt $\mathrm{P}$, Moller T: Neuroinflammation in the pathogenesis of amyotrophic lateralsclerosis. Neuro Report 2005, 16:527-531.

47. Jung HW, Yoon CH, Park KM, Han HS, Park YK: Hexane fraction of Zingiberis Rhizoma Crudus extract inhibits the production of nitric oxide and proinflammatory cytokines in LPS-stimulated BV2 microglial cells via the NF-kappaB pathway. Food and Chem Toxicol 2009, 47:1190-1197.

48. Lee MH, Kim JY, Ryu JH: Prenylflavones from Psoralea corylifolia Inhibit Nitric Oxide Synthase Expression through the Inhibition of $\mathrm{I}-\kappa \mathrm{B}$ aDegradation in Activated Microglial Cells. Biol Pharm Bull 2005, 28:2253-2257.

49. Chang LC, Tsao LT, Chang CS, Chen CJ, Huang LJ, Kuo SC, Lin RH, Wang JP: Inhibition of nitric oxide production by the carbazole compound LCY-2CHO via blockade of activator protein-1 and CCAAT/enhancer-binding protein activation in microglia. Biochem Pharmacol 2008, 76:507-519.

50. Justicia C, Gabriel C, Planas AM: Activation of the JAK/STAT pathway following transient focal cerebral ischemia: signaling through Jak1 and Stat3 in astrocytes. Glia 2000, 30:253-270.

51. Satriotomo I, Kellie K, Bowen RV: JAK2 and STAT3 activation contributes to neuronal damage following transient focal cerebral ischemia. J Neurochem 2006, 98:1353-1368.

52. Pawate $S$, Shen $Q$, Fan F, Bhat NR: Redox regulation of glial inflammatory response to lipopolysaccharide and interferongamma. J neurosci res 2004, 77:540-551.

53. Kim OS, Park EJ, Joe EH, Jou I: JAK-STAT signaling mediates gangliosidesinduced inflammatory responses in brain microglial cells. J Biol Chem 2002, 277:40594-40601.

54. Huang CF, Ma R, Sun SG, Wei GR, Fang Y, Liu RG, Li G: JAK2-STAT3 signaling pathway mediates thrombin-induced proinflammatory actions of microglia in vitro. J Neuroimmunol 2008, 204:118-125.

55. Natarajan C, Sriram S, Muthlan G, Bright JJ: Signaling through JAK2-STAT5 pathway is essential for IL-3-induced activation of microglia. Glia 2004, 45:188-196.

56. Hao YT, Yang XS, Chen CH, Wang Y, Wang XB, Li MQ, Yu ZP: STAT3 signalling pathway is involved in the activation of microglia induced by $2.45 \mathrm{GHz}$ electromagnetic fields. Int J Radiat Biol 2010, 86:27-36.

57. Nakamura Y: Regulating Factors for Microglial Activation. Biol Pharm Bull 2002, 25:945-953.

58. Righi M, Mori L, DeLibero G, Sironi M, Biondi A, Mantovani A, Donini SD, Ricciardi-Castagnoli P: Monokine production by microglial cell clones. Eur J Immunol 1989, 19:1443-1448.

59. Corradin SB, Mauël J, Donini SD, Quattrocchi E, Ricciardi-Castagnoli P: Inducible nitric oxide synthase activity of cloned murine microglial cells. Glia 1993, 7:255-262.

60. Bahr A, Bolz T, Hennes C: Numerical dosimetry ELF: Accuracy of the method, variability of models and parameters, and the implication for quantifying guidelines. Health Phys 2007, 92:521-530.

61. Kreutzberg GW: Microglia: a sensor for pathological events in the CNS. Trends Neurosci 1996, 19:312-318.
62. Liva SM, Kahn MA, Dopp JM, de Vellis J: Signal Transduction Pathways induced by GM-CSF in Microglia: Significance in the Control of Proliferation. Glia 1999, 26:344-352

63. Ling EA, Wong WC: The origin and nature of ramified and amoeboid microglia: a historical review and current concepts. Glia 1993, 7:9-18.

64. Rock RB, Gekker G, Hu S, Sheng WS, Cheeran M, Lokensgard JR, Peterson PK: Role of microglia in central nervous system infections. Clin Microbiol Rev 2004, 17:942-964.

65. Roy A, Fung YK, Liu XJ, Pahan K: Up-regulation of Microglial CD11b Expression by Nitric Oxide. J Biol Chem 2006, 281:14971-14980.

66. Shuai K, Stark GR, Kerr IM, Darnell JE Jr: A single phosphotyrosine residue of Stat91 required for gene activation by interferon-gamma. Science 1993, 261:1744-1746.

67. Stark GR, Kerr IM, Williams BR, Silverman RH, Schreiber RD: How cells respond to interferons? Annu Rev Biochem 1998, 67:227-264.

68. González-Scarano F, Baltuch G: Microglia as mediators of inflammatory and degenerative diseases. Annu Rev Neurosci 1999, 22:219-240.

69. Kudo M, Fujita K, Niyaz M, Matsuyama N: Immunohistochemical findings that exposure to $915 \mathrm{MHz}$ Global System for Mobile Communications (GSM) mobile phone microwaves activates microglia in rat brain. J Tokyo Med Univ 2007, 65:29-36.

70. Thorlin T, Rouquette JM, Hamnerius $Y$, Hansson E, Persson M, Björklund $U$, Rosengren L, Rönnbäck L, Persson M: Exposure of cultured astroglial and microglial brain cells to $900 \mathrm{MHz}$ microwave radiation. Radiat Res 2006, 166:409-421.

71. Finnie JW, Cai H, Manavis J, Helps S, Blumbergs PC: Microglial activation as a measure of stress in mouse brains exposed acutely (60 minutes) and long-term ( 2 years) to mobile telephone radiofrequency fields. Pathol 2010, 42:151-154.

72. Hirose H, Sasaki A, Ishii N, Sekijima M, Iyama T, Nojima T, Ugawa Y: 1950 MHz IMT-2000 Field Does Not Activate Microglial Cells In Vitro. Bioelectromagnetics 2010, 31:104-112.

73. IEEE EMF HEALTH \& SAFETY STANDARDS. [http://www.who.int/peh-emf/ meetings/southkorea/en/IEEE_EMF_HEALTH___Mason.pdf].

74. Block ML, Zecca L, Hong JS: Microglia-mediated neurotoxicity: uncovering the molecular mechanisms. Nat Rev Neurosci 2007, 8:57-69.

75. Dheen ST, Kaur C, Ling EA: Microglial activation and its implications in the brain diseases. Curr Med Chem 2007, 14:1189-1197.

76. Choi SH, Lee DY, Kim SU, Jin BK: Thrombin-induced oxidative stress contributes to the death of hippocampal neurons in vivo: role of microglial NADPH oxidase. J Neurosci 2005, 25:4082-4090.

77. Tian DS, Xie MJ, Yu ZY, Zhang Q, Wang YH, Chen B, Chen C, Wang W: Cell cycle inhibition attenuates microglia induced inflammatory response and alleviates neuronal cell death after spinal cord injury in rats. Brain Res 2007, 1135:177-185.

78. Zhang $L$, Wu CF, Meng XL, Yuan D, Cai XD, Wang QL, Yang JY: Comparison of inhibitory potency of three different curcuminoid pigments on nitric oxide and tumor necrosis factor production of rat primary microglia induced by lipopolysaccharide. Neurosci Lett 2008, 447:48-53.

79. Gebicke-Haerter PJ, Van Calker D, Nörenberg W, Illes P: Molecular mechanisms of microglial activation. A. Implications for regeneration and neurodegenerative diseases. Neurochem Int 1996, 29:1-12.

80. De-Fraja C, Conti L, Magrassi L, Govoni S, Cattaneo E: Members of the JAK STAT proteins are expressed and regulated during development in the mammalian forebrain. J Neurosci Res 1998, 54:320-330

81. Kim HY, Park EJ, Joe EH, Jou I: Curcumin suppresses Janus kinase-STAT inflammatory signaling through activation of Src homology 2 domaincontaining tyrosine phosphatase 2 in brain microglia. J Immunol 2003, 171:6072-6079.

82. Liang YJ, Jin Y, Li YN: Expression of JAKs/STATs pathway molecules in rat model of rapid focal segmental glomerulosclerosis. Pediatr Nephrol 2009, 24:1661-1671

83. Choi WH, Ji KA, Jeon SB, Yang MS, Kim H, Min KJ, Shong M, Jou I, Joe EH: Anti-inflammatory roles of retinoic acid in rat brain astrocytes: suppression of interferon-gamma-induced JAK/STAT phosphorylation. Biochem Biophys Res Commun 2005, 329:125-131.

84. Okada S, Nakamura M, Katoh H, Miyao T, Shimazaki T, Ishii K, Yamane J, Yoshimura A, Iwamoto $Y$, Toyama Y, Okano H: Conditional ablation of Stat3 or Socs3 discloses a dual role for reactive astrocytes after spinal cord injury. Nat Med 2006, 12:829-834. 
85. Leung YK, Pankhurst M, Dunlop SA, Ray S, Dittmann J, Eaton ED, Palumaa P, Sillard R, Chuah MI, West AK, Chung RS: Metallothionein induces a regenerative reactive astrocyte phenotype via JAK/STAT and RhoA signalling pathways. Exp Neurol 2010, 221:98-106.

86. Hashioka S, Klegeris A, Schwab C, McGeer PL: Interferon-gammadependent cytotoxic activation of human astrocytes and astrocytoma cells. Neurobiol Aging 2009, 30:1924-1935.

87. Pedranzini L, Dechow T, Berishaj M, Comenzo R, Zhou P, Azare J, Bornmann W, Bromberg J: Pyridone6, apan-Janus-activated kinase inhibitor, induces growth in hibition of multiple myeloma cells. Cancer Res 2006, 66:9714-9721.

88. Lucet IS, Fantino E, Styles M, Bamert R, Patel O, Broughton SE, Walter M, Burns CJ, Treutlein H, Wilks AF, Rossjohn J: The structural basis of Janus kinase 2 inhibition by a potent and specific pan-Janus kinase inhibitor. Blood 2006, 107:176-183.

89. Chang Y, Lee JJ, Hsieh CY, Hsiao G, Chou DS, Sheu JR: Inhibitory effects of ketamine on lipopolysaccharide-induced microglial activation. Mediators Inflamm 2009, 2009:705379.

90. Ryu J, Pyo H, Jou I, Joe E: Thrombin induces NO release from cultured rat microglia via protein kinase $C$, mitogen-activated protein kinase, and NF-kappa B. J Biol Chem 2000, 275:29955-29959.

91. Peterson PK, Hu S, Salak-Johnson J, Molitor TW, Chao CC: Differential production of and migratory response to chemokines by human microglia and astrocytes. J Infect Dis 1997, 175:478-481.

92. Pfitzner E, Kliem S, Baus D, Litterst CM: The role of STATs in inflammation and inflammatory diseases. Curr Pharm Des 2004, 10:2839-2850.

93. Yu H, Pardoll $D$, Jove R: STATs in cancer inflammation and immunity: a leading role for STAT3. Nat Rev Cancer 2009, 9:798-809.

94. Tanabe K, Matsushima-Nishiwaki R, Yamaguchi S, lida H, Dohi S, Kozawa O: Mechanisms of tumor necrosis factor- $\alpha$-induced interleukin- 6 synthesis in glioma cells. J Neuroinflammation 2010, 7:16.

95. Mir M, Tolosa L, Asensio VJ, Lladó J, Olmos G: Complementary roles of tumor necrosis factor alpha and interferon gamma in inducible microglial nitric oxide generation. J Neuroimmunol 2008, 204:101-109.

96. Du F, Yin L, Shi M, Cheng H, Xu X, Liu Z, Zhang G, Wu Z, Feng G, Zhao G Involvement of microglial cells in infrasonic noise-induced stress via upregulated expression of corticotrophin releasing hormone type 1 receptor. Neuroscience 2010, 167:909-919.

97. Liu JL, Tian DS, Li ZW, Qu WS, Zhan Y, Xie MJ, Yu ZY, Wang W, Wu G: Tamoxifen alleviates irradiation-induced brain injury by attenuating microglial inflammatory response in vitro and in vivo. Brain Res 2010, 1316:101-111.

98. Hwang SY, Jung JS, Kim TH, Lim SJ, Oh ES, Kim JY, Ji KA, Joe EH, Cho KH, Han IO: lonizing radiation induces astrocyte gliosis through microglia activation. Neurobiol Dis 2006, 21:457-467.

99. de Gannes FM, Merle M, Canioni P, Voisin PJ: Metabolic and cellular characterization of immortalized human microglial cells under heat stress. Neurochem Int 1998, 33:61-73.

100. Matsui T, Kakeda T: IL-10 Production Is Reduced by Hypothermia but Augmented by Hyperthermia in Rat Microglia. J Neurotrauma 2008, 25:709-716.

doi:10.1186/1742-2094-7-54

Cite this article as: Yang et al:: The role of the JAK2-STAT3 pathway in pro-inflammatory responses of EMF-stimulated N9 microglial cells. Journal of Neuroinflammation 2010 7:54.

\section{Submit your next manuscript to BioMed Central and take full advantage of:}

- Convenient online submission

- Thorough peer review

- No space constraints or color figure charges

- Immediate publication on acceptance

- Inclusion in PubMed, CAS, Scopus and Google Scholar

- Research which is freely available for redistribution

Submit your manuscript at www.biomedcentral com/submit
Biomed Central 